Biochimica et Biophysica Acta, 575 (1979) 174-182

(C) Elsevier/North-Holland Biomedical Press

BBA 57451

\title{
STUDIES ON THE TRANSVERSE LOCALIZATION OF LYSOPHOSPHOLIPASE II IN BOVINE LIVER MICROSOMES BY IMMUNOLOGICAL TECHNIQUES
}

\author{
HANS MOONEN and HENK VAN DEN BOSCH \\ Laboratory of Biochemistry, State University of Utrecht, Transitorium 3, Padualaan 8, \\ De Uithof, 3508 TB Utrecht (The Netherlands)
}

(Received February 20th, 1979)

Key words: Lysophospholipase; Transmembrane localization; Immunoprecipitation; (Bovine liver microsome)

\section{Summary}

1. Lysophospholipase activity solubilized from bovine liver microsomes could be precipitated for more than $80 \%$ by antibodies evoked in rabbits against the purified bovine liver lysophospholipase II.

2. After solubilization of the microsomes in $1.5 \%$ sodium deoxycholate, an immunoprecipitate containing lysophospholipase II in enzymically active form could be isolated.

3. Microsomal lysophospholipase activity was completely inhibited by $\left[{ }^{3} \mathrm{H}\right]$ diisopropylphosphofluoridate. Enzyme labelled in this way was isolated by immunoprecipitation from control and chymotrypsin-treated microsomes. Sodium dodecyl sulfate disc gel electrophoresis of the immunoprecipitates showed that chymotrypsin treatment of intact microsomes had no influence on the molecular weight of the enzyme.

4. Attempts to label the lysophospholipase II in microsomes by lactoperoxidase catalyzed iodination or by reaction with the diazonium salt of [ $\left.{ }^{125} \mathrm{I}\right]$ iodosulfanilic acid were negative, although both techniques labelled other microsomal proteins efficiently.

5. Antibody absorption experiments gave no indication for the presence of lysophospholipase antigenic sites on the outside surface of microsomes.

6 . These experiments are interpreted to indicate that lysophospholipase II is exclusively located at the luminal side of the microsomal membrane.

\section{Introduction}

De Jong et al. [1] purified two enzymes with lysophospholipase activity (EC 3.1.1.5) from bovine liver. Subcellular distribution studies showed lyso- 
phospholipase I to be located mainly in the cytosol and the mitochondrial matrix fraction, whereas lysophospholipase II exhibited its highest relative specific activity in the microsomes [2]. The solubility of the purified lysophospholipase II in water and the observation that the enzyme can be solubilized from microsomes by sonication with complete retention of its activity tends to classify it as a peripheral membrane protein. Experiments with proteoly tic enzymes to determine the transverse localization of the microsomal lysophospholipase showed that at least the active center of the enzyme is located at the luminal side of the beef liver microsomal membrane [3]. The present paper deals mainly with immunological experiments to get more insight in the transverse localization of the whole enzyme molecule in the microsomal membrane.

\section{Materials and Methods}

Materials. Chymotrypsin $\mathrm{A}_{4}$, trypsin (both from bovine), trypsin inhibitor from soya bean and from hen egg white were all products from Boehringer, Mannheim, F.R.G. Lactoperoxidase from milk was obtained from Sigma. $\left[1,3-{ }^{3} \mathrm{H}\right]$ diisopropylphosphofluoridate (spec. act. $3.4 \mathrm{Ci} / \mathrm{mmol}$ ) and ${ }^{125} \mathrm{I}$, carrier free, were purchased from the Radiochemical Centre, Amersham, U.K. [ $\left.{ }^{125} I\right]-$ Iodosulfanilic acid, as a labelling kit, was a product from NEN, Boston, U.S.A. Fresh bovine liver was obtained from the local slaughterhouse.

Methods. Isolation, incubation with proteolytic enzymes and sonication of microsomes were done as described before [3]. In all procedures $0.25 \mathrm{M}$ sucrose, $2 \mathrm{mM}$ EDTA, $10 \mathrm{mM}$ Tris, pH 7.4, 0.02\% (w/v) $\mathrm{NaN}_{3}$ was used as buffer (sucrose medium).

Lysophospholipase assays were done according to de Jong et al. [1] and protein was estimated to Lowry et al. [4]. Iodination of purified lysophospholipase II was done by the chloroamine-T method as described by Hudson and Hay [5].

Antiserum against lysophospholipase II was evoked in rabbits according to de Jong et al. [6]. Sera were brought to $45 \%$ saturation with $\left(\mathrm{NH}_{4}\right)_{2} \mathrm{SO}_{4}$. The immunoglobulins were dissolved in water, freed from salt by dialysis against water, lyophilized and stored at $-20^{\circ} \mathrm{C}$. Immunoprecipitation of microsomalbound lysophospholipase II and lactoperoxidase-catalyzed iodination of microsomes with ${ }^{125} \mathrm{I}$ and $\mathrm{H}_{2} \mathrm{O}_{2}$ was carried out according to the method of Welton et al. [7]. Labelling of microsomes with the diazonium salt of $\left[{ }^{125} I\right]$ iodosulfanilic acid was done as described by Nilsson et al. [8]. Antibody concentrations were determined by incubating fixed amounts of antibody solutions with increasing amounts of ${ }^{125} \mathrm{I}$-labelled lysophospholipase in sucrose medium. After incubation for $1 \mathrm{~h}$ at $37^{\circ} \mathrm{C}$ and two days in the cold room immunoprecipitates were isolated by centrifugation in a SS 34 Sorvall rotor at $10000 \mathrm{rev} / \mathrm{min}$ for 20 $\min$. The amount of precipitated enzyme was measured by determination of ${ }^{125}$ I radioactivity in the supernatant. Immunoprecipitates were washed three times with $1 \mathrm{ml}$ sucrose medium and then dissolved in the protein assay mixture to measure the protein content as described by Lowry et al. [4]. ${ }^{125}$ I radioactivity was determined in an aliquot of the protein assay mixture to calculate the recovery of the precipitate after the washing procedure. 
SDS disc gel electrophoresis was done by the method of Fairbanks et al. [9] or of Laemmli [10]. After staining the gels were sliced in fractions of $1 \mathrm{~mm}$. These were destructed with $250 \mu \mathrm{l} 30 \% \mathrm{H}_{2} \mathrm{O}_{2}$ overnight at $50{ }^{\circ} \mathrm{C} .{ }^{3} \mathrm{H}$ radioactivity was measured after addition of $16 \mathrm{ml}$ dioxane containing $10 \%$ naphthalene, $0.7 \%$ PPO and $0.03 \%$ POPOP.

\section{Results}

In a previous report we have shown that the lysophospholipase activity of bovine liver microsomes could be solubilized by sonication [3]. The supernatant obtained after centrifugation of the sonicated microsomes for $1 \mathrm{~h}$ at $200000 \times g$ was incubated with increasing amounts of antibodies against bovine liver lysophospholipase II. After removing the immunoprecipitates by centrifugation, the supernatants were tested for lysophospholipase activities. Surprisingly, $19 \%$ of the lysophospholipase activity could not be precipitated with the antiscrum (Fig. 1), in spite of previous observations that the lysophospholipase activity solubilized by sonication cochromatographed with pure ${ }^{125}$ I-labelled lysophospholipase II on AcA 44 [3] and DE-52 cellulose columns (data not shown). However, at least $80 \%$ of the lysophospholipase activity in bovine liver microsomes can be assigned to lysophospholipase II.

The total microsomal lysophospholipase activity could be rapidly inactivated by treatment with diisopropylphosphofluoridate. SDS disc gel electrophoresis of $\left[{ }^{3} \mathrm{H}\right]$ diisopropylphosphofluoridate-treated microsomes gave two peaks of radioactivity. The major part of the radioactivity (more than 90\%) was located in proteins with an estimated molecular weight of 65000 . The second small peak had a relative mobility expected for proteins with a molecular
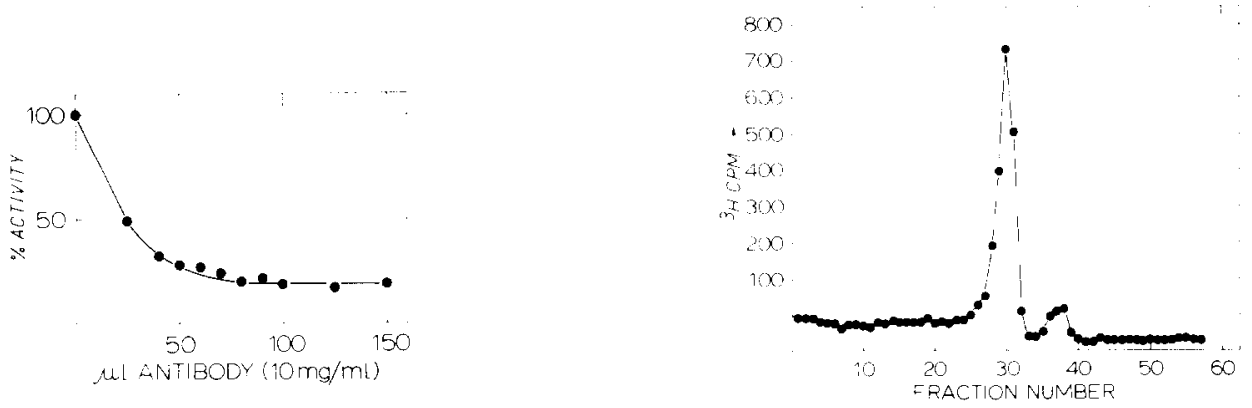

Fig. 1. Immunoprecipitation of lysophospholipase activity solubilized from bovine liver microsomes by sonication. Beef liver microsomes (17.5 mg protein) were sonicated during $15 \mathrm{~min}$ under $\mathrm{N}_{2}$ at $0^{\circ} \mathrm{C}$ in $7 \mathrm{ml}$ sucrose medium with a Branson Sonifier at $70 \mathrm{~W}$ output. The mixture was centrifuged for $1 \mathrm{~h}$ at $200000 \times g$. Aliquots of $0.5 \mathrm{ml}$ of the supernatant were incubated with the indicated amounts of antibodies in a total volume of $0.7 \mathrm{ml}$. Control immunoglobulines were added to each tube to give a final immunoglobulin concentration of $1.5 \mathrm{mg}$. After two days at $4^{\circ} \mathrm{C}$ immunoprecipitates were removed by centrifugation and $0.5 \mathrm{ml}$ of the supernatant was used for lysophospholipase assays.

Fig. 2. SDS disc gel electrophoresis of $\left[{ }^{3} \mathrm{H}\right]$ diisopropylphosphofluoridate-treated microsomes. Microsomes $(10 \mathrm{mg} / \mathrm{ml})$ were incubated for $30 \mathrm{~min}$ at $37^{\circ} \mathrm{C}$ with $2 \mathrm{mM}\left[{ }^{3} \mathrm{H}\right]$ diisopropylphosphofluoridate (spec. act. about $20000 \mathrm{cpm} / \mathrm{nmol}$ ) in sucrose medium. The mixture was then extracted according to Bligh and Dyer [11] and the water/methanol layer was lyophilized. The residue was dissolved in SDS buffer and an aliquot corresponding to $1 \mathrm{mg}$ protein was applied to the gel. Electrophoresis was done as described by Fairbanks et al. [9] . 
weight of 45000 (Fig. 2). It appeared possible to isolate specifically the lysophospholipase II by immunoprecipitation from the rest of the microsomal proteins after solubilization of the microsomal membrane with $1.5 \%$ sodium deoxycholate according to Welton et al. [7]. Thus, when unlabelled microsomes were solubilized with sodium deoxycholate the added ${ }^{125}$ I-labelled lysophospholipase II was recovered for about $90 \%$ in the immunoprecipitates (Table I). In addition, the lysophospholipase in the immunoprecipitate was still enzymically active. The fact that only about $40 \%$ of the enzymic activity is recovered in the immunoprecipitate may be related to the presence of inhibiting antibodies. We have previously observed that the activity of the enzyme in immunoprecipitates amounts to $50 \%$ of that found for the free enzyme [6]. The further loss of enzymic activity is ascribed to the treatment with the rather high concentration of sodium deoxycholate required to solubilize the microsomal membranes. At any rate, the amount of lysophospholipase activity precipitable by antibodies is not significantly decreased by preincubation of the microsomes with trypsin neither in the absence nor in the presence of $0.05 \%$ deoxycholate. Analysis of immunoprecipitates by SDS disc gel electrophoresis (Fig. 3) showed four main bands. With the aid of marker proteins (bovine serum albumin, ovalbumin, bovine immunoglobulin $G$ and lysophospholipase) these bands were assigned to lysophospholipase (fraction $38, M_{\mathrm{r}} 64000$ ), immunoglobulin heavy chain (fraction $45, M_{\mathrm{r}} 53000$ ) and immunoglobulin light chain (fraction $65, M_{\mathrm{r}} 26000$ ). The nature and origin of the fourth, contaminating, band (fraction $48, M_{\mathrm{r}} 48000$ ) was not further

\section{TABLE I}

IMMUNOPRECIPITATION OF LYSOPHOSPHOLIPASE II FROM BOVINE LIVER MICROSOMES SOLUBILIZED WITH SODIUM DEOXYCHOLATE

Microsomes ( $5 \mathrm{mg}$ protein, $26 \mathrm{mU}$ of lysophospholipase) in $0.5 \mathrm{ml}$ sucrose medium were incubated for 30 min at $37^{\circ} \mathrm{C}$ with $0.5 \mathrm{mg}$ trypsin and $0.25 \mathrm{mg}$ sodium deoxycholate as indicated. Trypsin activity was blocked by $1 \mathrm{mg}$ of trypsin inhibitor from hen egg white. Microsomes were solubilized by addition of an equal volume of $3 \%(\mathrm{w} / \mathrm{v})$ sodium deoxycholate in sucrose medium. A small quantity of $125 \mathrm{I}$-labelled ly sophospholipase II ( $2 \mu \mathrm{g} ; 0.8 \mathrm{mU})$ was added and the mixture was centrifuged for $1 \mathrm{~h}$ at $200000 \times \mathrm{g}$ to remove traces of insoluble material. The ${ }^{125} \mathrm{I}$ radioactivity was quantitatively recovered in the supernatant. Excess antibodies (10 $\mathrm{mg}$ protein) were added to the supernatants, which made the final sodium deoxycholate concentration $1 \%(\mathrm{w} / \mathrm{v})$. After $1 \mathrm{~h}$ at $37^{\circ} \mathrm{C}$ and 2 days at $4^{\circ} \mathrm{C}$, immunoprecipitates were isolated by centrifugation and washed three times with $1 \mathrm{ml}$ sucrose medium containing $1 \%$ sodium deoxycholate. The precipitates were resuspended in sucrose medium to measure 125 I radioactivity, protein content and lysophospholipase activity. Calculated total amounts of protein were obtained from measured values corrected for recovery of 125 I-labelled lysophospholipase.

\begin{tabular}{|c|c|c|c|c|c|}
\hline \multicolumn{2}{|l|}{ Addition } & \multicolumn{4}{|c|}{ Immunoprecipitate } \\
\hline Trypsin & $\begin{array}{l}\text { Sodium } \\
\text { deoxycholate }\end{array}$ & $\begin{array}{l}\text { Recovery } \\
125 \text { I-labelled } \\
\text { lysophospholi- } \\
\text { pase (\%) }\end{array}$ & $\begin{array}{l}\text { Total protein } \\
\text { (measured } \mu g \text { ) }\end{array}$ & $\begin{array}{l}\text { Total protein } \\
\text { (calculated } \\
\mu \mathrm{g})\end{array}$ & $\begin{array}{l}\text { Lysophospholipase } \\
\text { activity (mU) }\end{array}$ \\
\hline- & - & 95 & 310 & 326 & 9.1 \\
\hline - & - & 82 & 285 & 348 & 10.2 \\
\hline+ & - & 73 & 220 & 301 & 10.2 \\
\hline+ & 一 & 92 & 360 & 391 & 8.5 \\
\hline+ & + & 94 & 320 & 340 & 9.0 \\
\hline+ & + & 88 & 300 & 341 & 11.3 \\
\hline
\end{tabular}




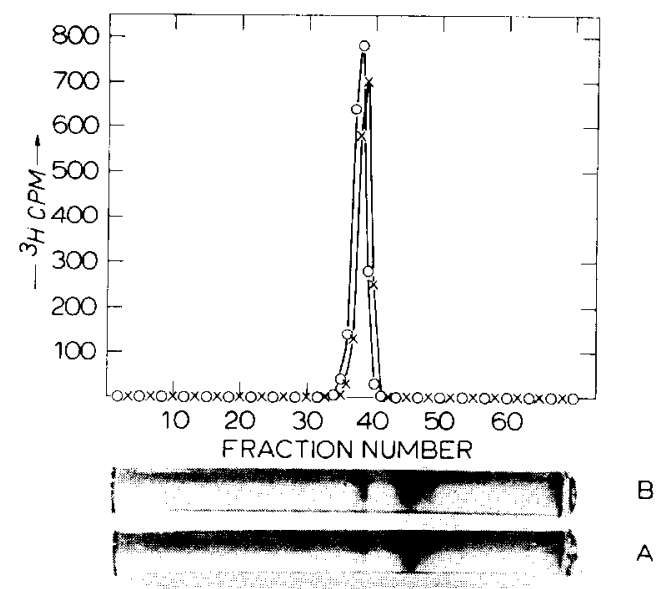

Fig. 3. SDS disc gel electrophoresis of $\left[{ }^{3} \mathrm{H}\right]$ diisopropylphospho-lysophospholipase II isolated by immunoprecipitation. Microsomes ( $30 \mathrm{mg}$ protein, $90 \mathrm{mU}$ lysophospholipase) were incubated overnight at $4^{\circ} \mathrm{C}$ with $250 \mu \mathrm{Ci}\left[{ }^{3} \mathrm{H}\right]$ diisopropylphosphofluoridate (spec. act. about $0.5 \mu \mathrm{Ci} / \mathrm{nmol}$ ) in $1.2 \mathrm{ml}$ sucrose medium. Excess $\left[{ }^{3} \mathrm{H}\right]$ diisopropylphosphofluoridate was removed by centrifugation. The pellet was resuspended in $3 \mathrm{ml}$ sucrose medium and divided in three fractions. One fraction served as control, the other fractions were incubated with $1 \mathrm{mg}$ chymotrypsin either in presence or absence of $400 \mathrm{nmol}$ egg lysophosphatidylcholine/mg microsomal protein. Chymotrypsin action was stopped after $0.5 \mathrm{~h}$ by addition of trypsin inhibitor from soybean as described before [3]. Microsomes were pelleted by centrifugation ( $1 \mathrm{~h}$ at $200000 \times g)$, resuspended in $1 \mathrm{ml}$ sucrose medium containing $3 \%(\mathrm{w} / \mathrm{v})$ sodium deoxycholate and centrifuged as above to remove traces of insoluble material. To the supernatants 2 ml immunoglobulin solution (16. $\mathrm{mg}$ protein $/ \mathrm{ml}$ ) were added. After two days in the cold room the immunoprecipitates were isolated and washed three time with $1 \%$ sodium deoxycholate in sucrose medium. An aliquot equivalent to $100 \mu \mathrm{g}$ of protein was applied on SDS disc gels according to Lacmmli [10]. After staining with Coomassie blue the gels were sliced and ${ }^{3} \mathrm{H}$ radioactivity in the slices was determined. (A) immunoprecipitate of control microsomes; (B) ibid of chymotrypsin-treated microsomes: $-0,{ }^{3} \mathrm{H}$ radioactivity distribution in gel (A); $X$

investigated. In the experiment depicted in Fig. 3A the microsomes were preincubated with $\left[{ }^{3} \mathrm{H}\right]$ diisopropylphosphofluoridate to label the lysophospholipase. As expected the microsomal proteins with an estimated molecular weight 45000 (compare Fig. 2) did not show up in the immunoprecipitate. We have shown previously [3] that chymotrypsin could not inactivate the lysophospholipase in inact microsomes, indicating that at least the active site of the enzyme was either buried in the membrane or located at the luminal site. It could not be excluded from such experiments whether a peptide had been removed by chymotrypsin from the enzyme at the cytoplasmic side with retention of lysophospholipase activity. To investigate this possibility the chymotrypsin treatment was repeated with microsomes prelabelled with $\left[{ }^{3} \mathrm{H}\right]$ diisopropylphosphofluoridate. As can be seen in Fig. 3B the molecular weight of the lysophospholipase isolated after this treatment is identical to that of the enzyme in control microsomes. Moreover, the total amount of radioactivity in the immunoprecipitate is identical to that of control microsomes. When the prelabelled microsomes were treated with chymotrypsin in the presence of egg lysophosphatidylcholine, an agent known to disrupt the microsomal permeability barrier [3], no immunoprecipitate could be isolated. These results indicate that chymotrypsin does not cleave any peptide from the lysophospholipase in intact microsomes, either because no part of the lysophospholipase is exposed at the outside surface of the microsomes or the part exposed has no 
chymotrypsin or trypsin-cleavable peptide bonds. To further investigate whether any part of the lysophospholipase is exposed at the outside surface of the microsomes use was made of impermeable labelling reagents. Thus, intact microsomes were incubated with lactoperoxidase and ${ }^{125} \mathrm{I}$ in the presence of $\mathrm{H}_{2} \mathrm{O}_{2}$ according to Welton et al. [7] or with the diazonium salt of $\left[{ }^{125} \mathrm{I}\right]$ iodosulfanilic acid according to Nilsson et al. [8]. Although membrane proteins were labelled efficiently in both cases, no label was found in the lysophospholipase after immunoprecipitation.

In another approach to see if part of the lysophospholipase was located at the outside surface of the microsomes use was made of an immunoabsorption technique. A solution containing antibodies against lysophospholipase II was treated with excess microsomes. After removal of the microsomes by centrifugation the amounts of residual antibodies in the supernatants were determined by incubation with increasing amounts of ${ }^{125}$ I-labelled lysophospholipase II. Fig. 4 shows the amounts of immunoprecipitates obtained with the treated antibody solutions. It is obvious that the optimal amount of immunoprecipitate that can be obtained from antibody solutions pretreated with either control or chymotrypsin-treated microsomes is about half that obtained with the original antibody solution. This can be caused by random absorption of immunoglobulins to the microsomes or by a specific absorption of antibodies against lysophospholipase II. It is possible to distinguish between these two possibilities by determining the ratio of antibody to antigen in the immunoprecipitates in the antibody excess zones of the curves in Fig. 4. At each point the $\mu \mathrm{g}$ lysophospholipase in the total immunoprecipitate can be calculated from the ${ }^{125}$ I radioactivity. As expected [5], when the ratio of antibody to antigen in the zones of antibody excess are plotted as a function of added antigen,
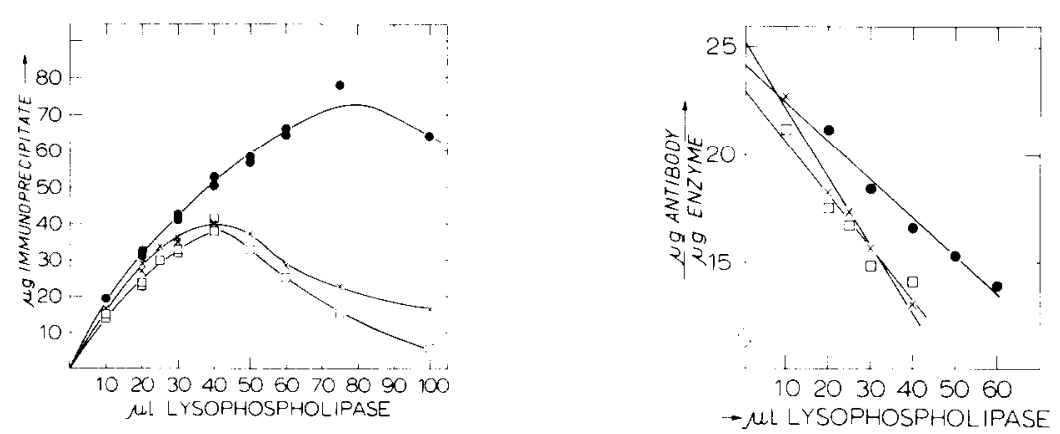

Fig. 4. Quantitative immunoprecipitation of fixed amounts of antibodies with increasing amounts of 125 I-labelled lysophospholipase II. Antibodies ( $40 \mathrm{mg}$ protein) in $4 \mathrm{ml}$ sucrose medium were incubated for $30 \mathrm{~min}$ at $25^{\circ} \mathrm{C}$ with $4 \mathrm{ml}$ sucrose medium (•——), with $4 \mathrm{ml}$ sucrose medium containing microsomes (82.5 mg protein; $250 \mathrm{mU}$ endogenous lysophospholipase) $(X--X)$ or with $4 \mathrm{ml}$ sucrose medium containing the same amount of microsomes after chymotrypsin treatment ( $\square-\square)$. The mixtures were centrifuged for $1 \mathrm{~h}$ at $105000 \times \mathrm{g}$ to remove the microsomes. Aliquots of $0.5 \mathrm{ml}$ of the supernatants were incubated for two days in the cold room with increasing amounts of 125 I-labelled lysophospholipase II $(84 \mu \mathrm{g} / \mathrm{ml}, 2000 \mathrm{cpm} / \mu \mathrm{g})$ as indicated. Immunoprecipitates were isolated by centrifugation and washed three times with sucrose medium before measurement of protein contents.

Fig. 5. Antibody to antigen ratio in immunoprecipitates at different levels of antibody excess. Ratios were calculated from determined amounts of 125 I-labelled lysophospholipase II and total amounts of protein in immunoprecipitates. Symbols as in legend Fig. 4. 
straight lines are obtained. The intercepts on the vertical axis give the antibody/ antigen ratios in the immunoprecipitate at a infinite antibody excess (Fig. 5). For the original antibody solution this value amounted to $24.2 \pm 0.7$, corresponding to a molar ratio of antibody to antigen of 10 . If the treatment of the antibody solution with excess microsomes had resulted in the specific absorption of antibodies to one or more antigenic determinants of the lysophospholipase the immunoprecipitate at infinite antibody excess would show a lower antibody/antigen ratio. On the other hand when the microsomes absorb antibodies randomly due to nonspecific protein-protein interactions the amount of residual antibodies in the supernatant will be less as observed in Fig. 4, but the composition of the immunoprecipitate at infinite antibody excess will remain unchanged. This is in fact observed in Fig. 5. The intercepts obtained for the antibody solutions after treatment with either control or chymotrypsintreated microsomes were calculated by least-squares analysis from the data in Fig. 5 to be $25.3 \pm 0.7$ and $23.0 \pm 1.1$, respectively. These data are not significantly different from the one obtained for the original antibody solution. From this we conclude that no antigenic sites of the lysophospholipase are located on the outside surface of bovine liver microsomes.

\section{Discussion}

It is not quite clear why the antibody preparation against lysophospholipase II did not completely precipitate the enzyme after it had been solubilized from bovine liver microsomes by sonication (Fig. 1). It has previously been shown that antibodies against lysophospholipase II do not cross-react with lysophospholipase I [6]. Therefore, the residual lysophospholipase activity in Fig. 1 could be due to the presence of lysophospholipase I in the microsomes. However, several arguments make this explanation unlikely. First, subcellular distribution studies have shown that lysophospholipase I is located in the cytosolic and mitochondrial matrix fraction and it contributes for at most $6 \%$ to the total lysophospholipase activity of the microsomal fraction [2]. Secondly, purified lysophospholipase $I$ is not or only very slowly inhibited by diisopropylphosphofluoridate [12]. Yet, all lysophospholipase activity in the microsomal fraction was rapidly inactivated by diisopropylphosphofluoridate (data not shown). Thirdly, the microsomal lysophospholipase activity after solubilization by sonication cochromatographed with purified ${ }^{125}$ I-labelled lysophospholipase II on DEAE-cellulose and AcA 44 columns [3]. Perhaps the lipids present in the supernatants after sonication prevented a complete precipitation of the lysophospholipase II. Removal of the lipids by $n$-butanol treatment has previously been shown to yield protein extracts from which lysophospholipase II could be completely precipitated by antibodies [6].

Treatment of liver microsomes with diisopropylphosphofluoridate not only inhibits lysophospholipase activity (EC 3.1.1.5) but also nonspecific carboxylesterases (EC 3.1.1.1) [13]. Liver carboxylesterases from a number of mammals such as pig, ox, rat and human consist of three subunits with a molecular weight of about 60000 each [14-16]. De Jong et al. [1] showed that ox liver carboxylesterase had no lysophospholipase activity. In addition, isoelectric focusing [1] and immunological experiments [6] indicated that lysophospho- 
lipase II and carboxylesterase are different protein entities. These findings show convincingly that the radioactivity peak seen in the SDS gel of Fig. 2 at the migration for proteins with a molecular weight of about 64000 must represent more than one protein species. Therefore, the total amount of radioactivity measured in this peak cannot be used to calculate the amount of either lysophospholipase II or carboxylesterase. Similar arguments hold, or course, for other organophosphate inhibitors. In this respect, the assumption made by Kunert and Heymann [17], that the amount of bis[p-nitro- $\left[{ }^{14} \mathrm{C}\right]$ phenyl]phosphate bound to pig liver microsomal proteins is a measure for the amount of carboxylesterase present may not be valid, in spite of the fact that these authors observed only one radioactive peak in SDS gels corresponding to proteins with a molecular weight of about 60000 . In principle it should be possible to calculate the amount of lysophospholipase in bovine liver microsomes from the specific radioactivity of $\left[{ }^{3} \mathrm{H}\right]$ diisopropylphosphofluoridate and the amount of ${ }^{3} \mathrm{H}$ radioactivity in the immunoprecipitate. However, since lysophospholipase, as discussed above, is not the only labelled protein it becomes impossible to determine the quantitative recovery of the ${ }^{3} \mathrm{H}$-labelled lysophospholipase in the immunoprecipitate. In addition, the exact specific radioactivity of $\left[{ }^{3} \mathrm{H}\right]$ diisopropylphosphofluoridate is difficult to determine due to instability of this reagent in aqueous solutions [18]. A rough estimate for the amount of lysophospholipase in bovine liver microsomes can be obtained from the data in Table II. Assuming that the recovery of the microsomal lysophospholipase in the immunoprecipitate is the same as for the added ${ }^{125}$ I-labelled cnzyme the total immunoprecipitate obtained from $5 \mathrm{mg}$ microsomal protein amounted to about $340 \mu \mathrm{g}$. It can be seen from Fig. 5 that the ratio of antibody to antigen in the immunoprecipitate in the antibody excess zone can vary from 14 till 24 depending on the antibody excess. With this much variation the amount of lysophospholipase in the immunoprecipitate can be calculated to be from 23 to $14 \mu \mathrm{g}$. In the experiments of Table I, $2 \mu \mathrm{g}$ of ${ }^{125} \mathrm{I}$ labelled enzyme were added. Hence, from 21 to $12 \mu \mathrm{g}$ lysophospholipase was present in $5 \mathrm{mg}$ microsomal protein. On the other hand, the amount of lysophospholipase in microsomes can be calculated from measurements of the activity of the enzyme, assuming that neither microsomal phospholipids nor the purification of the enzyme influence the activity. The specific activity of the lysophospholipase in the microsomes used in Table I at saturating substrate concentration was $5.2 \mathrm{nmol} \cdot \mathrm{min}^{-1} \cdot \mathrm{mg}^{-1}$. The activity of the purified enzyme was $1400 \mathrm{nmol} \cdot \mathrm{min}^{-1} \cdot \mathrm{mg}^{-1}$ [1]. From these data a value of $3.7 \mu \mathrm{g}$ lysophospholipase/mg microsomal protein can be calculated, which is in the range of the values deduced from the immunological experiments.

Several arguments support the view that bovine liver microsomal lysophospholipase is a peripheral membrane protein which is exclusively located on the luminal side of the microsomal membrane. Treatment of microsomes with proteolytic enzymes resulted only in loss of enzymic activity when the microsomal permeability barrier was destroyed, e.g. by lysophosphatidylcholine [3]. As shown in Fig. 3 treatment of intact microsomal vesicles with proteolytic enzymes caused no decrease in the molecular weight of the enzyme. Furthermore, no part of the enzyme molecule could be labelled by reaction of intact microsomes with lactoperoxidase and ${ }^{125} I$ or the diazonium salt of $\left[{ }^{125} I\right]$ iodo- 
sulfanilic acid. Finally, no antigenic determinants of the lysophospholipase could be detected at the outside surface of the microsomes (Figs. 4 and 5). The finding that the enzyme is located at the inside of the microsomal vesicle will be used to determine transbilayer movements of lysophosphatidylcholine over the microsomal membrane.

\section{Acknowledgements}

This study was carried out under the auspices of the Netherlands Foundation for Chemical Research (S.O.N.), with the financial aid from the Netherlands Organization for the Advancement of Pure Research (Z.W.O.).

\section{References}

1 De Jong, I.G.N., van den Boseh, H., Rijken, D. and van Deenen, L.L.M. (1974) Biochim. Biophys. Acta. $369,50-63$

2 Van den Bosch, H. and de Jong, J.G.N. (1975) Biochim. Biophys. Acta 398, 244-257

3 Moonen, H. and van den Bosch, H. (1979) Biochim. Biophys. Acta 573, 114-125

4 Lowry, O.H., Rosebrough, N.J., Farr, A.L. and Randall, R.J. (1951) J. Biol. Chem. 251, 4901-4907

5 Hudson, L, and Hay, F.C. (1976) Practial Immunology, Blackwell Scientific Publications, Oxford

6 De Jong, J.G.N., van den Besselaar, A.M.H.P. and van den Bosch, H. (1976) Biochim. Biophys. Acta, $441,221-230$

7 Welton, A.F., Pederson, T.C., Ruege, A.A. and Aust, S.D. (1973) Biochem. Biophys, Res. Commun. $54,161-167$

8 Nilsson, O.N., Arion, W.J.. Depierre, J.W., Dallner, G. and Ernster, L. (1978) Eur. J. Biochem. 82, $627-634$

9 Fairbanks, G., Steck, 'I.L. and Wallach, D.F.H, (1971) Biochemistry 10, 2606-2617

10 Laemmli, U.K. (1970) Nature $227,680-685$

11 Bligh, E.G. and Dyer, W.J. (1959) Can.J. Biochem. 37, 911-917

12 De Jong, J.G.N, (1975) Thesis, State University Utrecht

13 Krisch, K. (1970) Z. Klin. Chem. Klin. Biochem. 8, 545-551

14 Junge, W., Krisch, K, and Hollandt, H. (1974) Eur. J. Biochem. 43. 379-389

15 Arndt, R., Heymann, E., Junge, W. and Krisch, K. (1973) Eur. J. Biochem. 36, 120-128

16 Junge, W., Heymann, E., Krisch, K. and Hollandt, H. (1974) Arch. Biochem. Biophys. 165,749763

17 Kunert, M. and Heymann, E. (1975) FEBS Lett. 49, 292-296

18 Christopher, R.E. and Sheppard, G. (1975) Anal. Biochem. 68, 167-174 